\title{
Explicating the Nuances of Family Responsibility with Reference to Manju Kapur's Home
}

\section{OPEN ACCESS}

Manuscript ID:

ENG-2020-08033179

Volume: 8

Issue: 3

Month: June

Year: 2020

P-ISSN: 2320-2645

E-ISSN: 2582-3531

Received: 28.04 .2020

Accepted: 20.05.2020

Published: 02.06.2020

Citation:

Deviga, D., and M.

Ashitha Varghese.

"Explicating the Nuances of Family Responsibility with Reference to Manju Kapur's Home." Shanlax International Journal of English, vol. 8, no. 3, 2020, pp. 45-48.

DOI:

https://doi.org/10.34293/ english.v8i3.3179

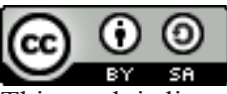

This work is licensed under a Creative Commons AttributionShareAlike 4.0 International License

\section{Deviga}

Ph.D. Research Scholar, Department of English and Foreign Languages

Bharathiar University, Coimbatore, Tamil Nadu, India

https://orcid.org/0000-0002-0425-3721

\section{Ashitha Varghese}

Assistant Professor, Department of English and Foreign Languages

Bharathiar University, Coimbatore, Tamil Nadu, India

\begin{abstract}
The research article emphasizes multidimensional themes of family issues considering the emergence of the independent identity of Nisha, a young daughter in the joint family. Her pretense as a self-standing woman turns down all the cultured family values inevitable for a daughter. Manju Kapur, as a proficient writer of the Indian family system, indicates her honest text in depicting the motif of woman's freedom and restoration in the patriarchal based society. Manju Kapur emerges as a new prodigy in Indian writing. She emerges as a noteworthy writer in the progression of Indian fiction.
\end{abstract}

Keyword: Indian family, Middle-class women, Marriage system, Tradition norms.

The fictional women characters of Manju Kapur are imagined to unveil the hidden secrets and techniques of penetrating beliefs, customs, rituals, and superstitions. They are the rebellion of inhibition, societal oppressive expectancies, joint own family regulations, and patriarchal obstacles in the society. They aren't the muted creatures but are bold sufficient to raise their voices for his or her selfhood and oppose the injustice and wrought. Their identity is constantly in a dichotomy between their inner aspirations and social mechanisms of surveillance. They mirror futile quests, disillusioned goals, longing for a domestic, ruining of identification, struggle for selfhood, which leaves behind not anything; however, anxiety, humiliation, and soreness.

The gift paper deals with Manju Kapur's novel "Home" (2006). The fiction is apparent for its focus upon the higher off of ladies' role in a household as well as in society. Kapur has evoked several societal evils, which might also include caste primarily based prejudice, classism, superstitious beliefs, prohibited female training, eradication of baby marriage, etc. The organization of marriage is an intimate oppressor to marginalize ladies in society. A lady is never wished to discuss her marital descendants. Love marriages are favored as a social sin and worthy of disgrace at the same time as organized marriages are considered with the eyes of admire and hope for dowry negotiations. To ruin the male dominance shackles, a woman calls for to impeach the popular prejudices and to reinvent their identity. However, it is not training best this is wanted. It is that women who must have the liberty of experience that they must range from guys without worry and express the one's variations brazenly.. be.. "encouraged to think, invent, imagine and create as freely as men do" (Woolf 32-33). 
The novel "Home" movements ahead through the depressing tale of surprisingly captivated Manju Kapur's female, Nisha, among her innermost desires and circle of relatives-orientated responsibilities and restrictions. The novel is a brisk account of three generations. It is a joint circle of relative's saga having Lala Banwarilal as its patriarch. It is a tremendous story of a middle-magnificence joint family. Each man or woman's voice might also chatter, complain, query; however, all fall silent to the commonplace pursuits of a family as a whole. One actual hassle of any person man or woman is handled with rejection. The depiction of the authentic question of one female by way of some other girl is the remaining final result of the novel. The love marriage of the elder son of Banwari Lal came up with plenty of abused remarks and seemed as a sin. While the organized marriage of the more youthful son is cheerfully welcomed and socially applauded because it enables us to have dowry blessings. The superstitious beliefs circulate hand in hand with the tale of the unconventional, for the imminent husband and keeping a fast are all well-known dangerous practices that are weakening the societal stems. The complexities of the unconventional are numberless as every cautious studying explores new dimensions of significance and meaning.

Manju Kapur had started scripting this novel in 1994. It would be her first novel if she did no longer sticks to the unconventional "Difficult Daughter." She acclaims that Home is not about her private evaluation; however, her highbrow wondering primarily based upon her educational enjoyment. She divulges it in one of her interviews, "I can analyze only because I am a trainer." She takes writing as a muscle which needs to be activated all of the time. She feels her life finished in coaching, domestic, and writing.

Kapur's new emblematic novel is a complicated tale of joint own family lifestyles. Lala Banwari Lal -the patriarch of the own family, believes inside the vintage methods. Anupama Chowdhury elaborates: "Home reveals a disturbing home truth that joint families can both destroy and preserve our maturity, individuality and mental progress." (Chowdhury, 33). With the advent of generation, the family in "Home" witnesses a series of new beginnings; to have newly considered technology, education, and exceptionally to find peace.

Men, in the circle of relatives, are carried forward to work outside the home even as their other halves are implied to play their element inside. The story focuses upon three generations of women - Sona (daughter-in-law of Banwari Lal), Rupa (Sona's sister) and Nisha (Sona's daughter). There are many implications and regulations within the writing which are only had to be ordinary by females. Mostly, it's far a woman who is providing compulsions upon another lady. Sona, the elder daughter-in-regulation of Banwari Lal, is forced to pour her motherly emotion into her dead sister-in-regulation's son against her desires. She is confined to publish to fate, "Beti, now you are his mother. God has rewarded your devotion. Sometimes our wishes are fulfilled in strange ways". (p.27). The discriminated emotions of their own family to her for being childless are comforted best after ten years of late birth of her first toddler, Nisha. Sona, because the victim of subordination and marginalization, now transforms into the representative of it. The pain she suffers is handed on into every other female individual of Kapur, Nisha.

The predominant part of the radical is devoted to Nisha, granddaughter of Banwari Lal. Through the individual of Nisha, Kapur consists of ahead the picture of our society, which portrays the photo of a lady as a subjugated being as a taken-for-granted component. However, Nisha's response to those antithetical forces offers every other floor of the novel. After overcoming her center hardships of lifestyles, Nisha does skip through a phase of disappointment; however, then emerges as an independent financial woman. Nisha's motion of emancipation from the border to the mainland cannot be beneath estimated within the given confined patriarchal structure of marginality in lady's lifestyles.

The start of Nisha brings success to the own family as her aunt exclaims, "Nisha has opened the good fortune of his own family. I let you know, two children in years after a decade of draught". Nisha, being luckiest for others, cannot deliver it for herself. She is physically exploited in her childhood through her growing cousin, Vicky. Her cries and rise up against those grimy fluctuations are not heard or 
understood. Her ache comes out inside the shape of nightmares and sleepless nights. The homily love and care are fetched from her in childhood as she is distanced from her aunt, Rupa. Her go back to her home after such a lot of years is not any manner approached with remarkable apprehension and gratitude. Her mom, Sona, subordinates her into household works. Eventually, Nisha, being a highbrow philosopher at her aunt's domestic, loses her educational interest in her college lifestyle.

From the conventional Indian society, a lady under patriarchal discrimination is focused to stay and survive social ostracism. They are handling a never-ending battle to enact an identical role to men in society. Manju Kapur's heroine, Nisha, is forced towards domesticity and so-referred to as the circle of relative's rituals beneath patriarchal notions. She is caught in a dichotomy between her private wants and institutional liabilities. However, Nisha defies the oppressive mechanism of a closed society and asserts her individualism. She nurtures her choice to guide lifestyles of her very own. She is not a silent riot; however, utters her internal urges loudly. She challenges the male exercising of getting manipulate over the lady's frame.

The unmarried girls of the twentieth century are still taken into consideration as a burden on her parents until she is married. She is seen as a spinster or a piece of shame if she marries overdue. Any love-affair before marriage is a sinful act on the part of a female. Unwed moms, unmarried or untrue women are assigned outcasts. Nisha's relationship with Suresh is looked like a big downfall inside the popularity of the own family. Emancipation and Rehabilitation in Manju Kapur's Home: A Study of Family Values International Journal on Studies in English Language and Literature. Against the bounded norms of the circle of relatives and to stay her life on her terms. She rejects to marry anyone of her family's desire. But what does her in reality get? Despite her difficult labor for self-fulfillment, she will become a loser in her efforts. She is alienated and discriminated against in her own family. Her younger brother is married earlier than her, which illnesses her mentally and bodily.

\section{Conclusion}

In the novels of Manju Kapur, girls are allowed to work out of doors the home. Even if they may be dealing with economic subjects or doing any process outside, she is denied any right on household matters. A wage-earning girl's first obligation is to handle the rate of the kitchen before her process. Nisha builds herself as, and a hit clothier, but her marriage with Arvind pushes her far away from her business. She is enslaved within her family obligations; dutiful daughter in regulation and spouse, motherhood, and so on. The quit manufactured from Nisha's plight cannot be seen in the attainment of victory or defeat however she satisfies her inner urge in her very own home, "Nisha's emancipation for her individuality and unbiased identity come to be not anything of use as she is located in rehabilitation as she finds her peace of thoughts in getting her domestic, her very own.

\section{References}

Abhrams, M.H. A Glossary of Literary Terms. Prism Books Pvt. Ltd, Bangalore, 1993.

Agrawal, Malti. "Manju Kapur's Home: A Chronicle of Urban Middle Class in India." Impressions: Bi-Annual E-Journal of English Studies, vol. 1, no 1, 2007.

Ali, Farzana. S. Novels of Manju Kapur: A Critical Study. Dattsons, India, 2015.

Beauvoir, Simone de. The Second Sex. Trans. \& Ed. Harmondworth. Penguin, H.M. Parshley.

Begum, Jameela A. "Postmodernism as Feminist Text: A Reading of the Short Text of Canadian Women Writers." Postmodernism and Feminism: Canadian Context, edited by Shirin Kudchedkar, Pencraft International, New Delhi, 2005.

Bhargava, Rajul. "Infidel Heteroglossia? Postmodernist Feminist Configurations in Githa Hariharan's The Art of Dying." Indian Writing in English: The Last Decade, edited by Rajul Bhargava, Rawat Publications, Jaipur, 2002.

Chowdhury, Anupama. "Manju Kapur's Home: A Feminist Reading". The Indian Journal of English Studies, Bani Press, Cuttak, vol. 45, 2008. 
Das, Bijay Kumar. Post modern Indian English Literature. Atlantic Publishers, New Delhi, 2010.

Dwivedi. A.N. "Manju Kapur's Home (2006): A Feminist Reading." Novels of Manju Kapur: A Feminist Study, edited by Ashok Kumar, Sarup Book Publishers Pvt. Ltd., New Delhi, 2010, pp. 38-45.

Gillingan, Carol. A Different Voice: Psychological Theory and Women's Development. Harvard University Press, Cambridge, 1982.

Irigaray Luce. and Hélène Vivienne Wenzel. "The One Doesn't Stir Without the Other." Signs, vol. 7, no. 1, 1981, pp. 60-67.

Jaidev. "Problematizing Feminism." Gender and Literature, edited by Iqbal Kaur, B.R. Publishing Corporation, New Delhi, 1992.

Kapur, Manju. Home. Random House, India, 2007.

Kapur, Manju. "One Minute With: Manju Kapur." Interview by Stimpson Jo, The Independent, 2009, http://www.independent.co.uk/artsentertainment/books/features/oneminutewith-manju-kapur-1660588.html.

Kapur, Manju. "The Writerly Life is Very Isolating." Interview by Farhad J. Dadyburjor. DNA INDIA. 2006, http://www.dnaindia.com/ report.asp?NewsID=1019404

Lal, Malashri. The Law of the Threshold: Women Writers in Indian English. Indian Institute of Advanced Study, Shimla, 1995.
Rajput, Kalpna. Remapping The Female Map: Jhumpa Lahiri and Manju Kapur. Yking Books, Jaipur, India, 2012.

Sharma, Ram. Rise of New Woman Novels of Manju Kapur. Manglam Publications, Delhi, 2013.

Sharma, Ram. "Quest for Feminine Identity in Manju Kapur's Novel Home.” Post Colonial Indian English Literature, Aavishkar Publishers \& Distributors, Jaipur, 2012, p. 66.

Singh, Jai Arjun."An Interview with Manju Kapur". Remapping the Female Map: Jhumpa Lahiri and Manju Kapur, edited by Kalpna Rajput. Yking books, Jaipur, 2012, pp.178- 182.

Sinha, Sunita. Post Colonial Women Writers: New Perspectives. Atlantic Publishers \& Distributors, New Delhi, 2008.

Srivastava, Sarika. "The Voice of Protest in the Novels of Manju Kapur." Novels of Manju Kapur: A Feministic Study. edited by Ashok Kumar. Sarup and Sons, New Delhi, 2010, pp. 93-109.

Velmani, N. "Woman's Abnormal Relationship as an Antidote for Masculine Superiority: A Study of Manju Kapur's Novels." The Atlantic Criterion, vol. 45, no. 4, 2010.

Warake, N.S. "Quest for Identity and Survival: A Study of Manju Kapur's Home." Journal of Literature, Culture and Media Studies, vol. 2, no. 4, 2010, pp. 268-278.

\section{Author Details \\ D. Deviga, Ph.D., Research Scholar, Department of English and Foreign Languages, Bharathiar University, Coimbatore, Tamil Nadu, India. Email ID: devigadina3@gmail.com.}

Dr. M. Ashitha Varghese, Assistant Professor, Department of English and Foreign Languages, Bharathiar University, Coimbatore, Tamil Nadu, India. 